\title{
Ebola in an unprepared Africa
}

\author{
Governments of affected countries need help but must take the lead in protecting their citizens
}

\author{
Oyewale Tomori professor of virology
}

Nigerian Academy of Science, University of Lagos Campus, Akoka, Lagos 100213, Nigeria

The 2 year old boy who died in December 2013 in Gueckedou, Guinea, is considered the index case of the current outbreak of Ebola virus disease caused by the Zaire species. ${ }^{1}$ Up until 2014, the disease was limited to rural areas of east and central Africa, ${ }^{2}$ but it has now spread to Liberia, Sierra Leone, Nigeria, and Senegal. By 6 September 2014, 4293 cases and 2296 deaths had been reported in the current outbreak, ${ }^{3}$ which, by the time the outbreak is controlled, is likely to surpass the total number of cases and deaths reported for all 22 Ebola outbreaks that have occurred in Africa since 1976, when the disease was first described. ${ }^{3}$ The World Health Organization has declared the current outbreak an "out of control" public health emergency of international concern. ${ }^{4}$

One of the reasons for the unprecedented epidemic is that Ebola is spreading in three countries ranked among the poorest in the world. The 2014 Human Development Index ranks Liberia, Guinea, and Sierra Leone at 175, 179, and 183, respectively, of 187 countries. ${ }^{5}$ Whereas Liberia and Sierra Leone are recovering from civil wars, Guinea has been affected by chronic underdevelopment allowed and ignored by successive governments. Around a fifth of the citizens of these three countries live in extreme poverty. ${ }^{6}$ Health facilities and services are wholly inadequate. For example, Liberia has 0.1 physicians, 1.7 nurses and midwives, and eight hospital beds for every 10 000 people. $^{7}$

To date, more than 240 healthcare workers have developed Ebola virus disease in Guinea, Liberia, Nigeria, and Sierra Leone and more than 120 have died. ${ }^{8}$ In addition to fragile health systems, several other contributory factors have compromised our ability to mount an adequate response. Poor disease surveillance and response systems make early detection and control of outbreaks inefficient and unreliable. In addition, unmanned borders artificially separate people of the same ethnic origin and cultural background into different nationalities, resulting in a high level of movement across borders and uncontrolled cross border movement of infected people. The death of healthcare workers has led to a shortage of workers to care for patients with other diseases and hospital closures. Ignorance and misconceptions about the virus's mode of transmission and customary burial ceremonies complicate the situation further.
Governments of affected countries were initially in denial over the occurrence of the disease. Subsequently, they relinquished responsibility for the care of infected patients to overworked international non-governmental organisations and issued incoherent directives, such as the closure of markets and borders. The Ebola outbreak has now become so serious that health infrastructure is beginning to collapse and hospitals are closing. Without effective medical care patients are dying not only of Ebola but of malaria, diarrhoea, and other conditions. The medical charity Médecins Sans Frontières recently commented that it will take at least another six months to bring the epidemic under control. ${ }^{9}$ The organisation's president and general director have described the international response to its repeated calls "for more hands-on assistance to control the epidemic and to provide the best possible care to patients" as "slow, derisory, [and] irresponsible." 10

\section{What must be done to stop transmission and control the epidemic?}

The current epidemic is beyond the capacity and capability of the affected nations. Ending the Ebola outbreak in west Africa and preventing a global calamity requires commitment and collaboration of national and international governments and agencies. The affected countries need urgent help with strengthening and sustaining basic infection control procedures to stop transmission of disease. These include daily tracking of people who come into contact with sick or dead people and monitoring them for the 21 day incubation period; documentation of historical and ongoing chains of virus transmission to ensure that accurate numbers of cases and deaths are recorded and to provide information on transmission of disease; identification of deaths in the community and ensuring safe burial practices; and improving specimen referral and strengthening laboratory diagnostic capacity. Healthcare workers must be educated on these practices to substantially reduce healthcare associated transmission.

National governments urgently need to communicate with the population to restore confidence and to ensure acceptance of healthcare services. They need to educate people on the community's role in control of the disease and to enumerate government action and efforts in controlling the disease. They 
must show leadership and assume responsibility for the welfare of their citizens by prioritising the provision of adequate funds for procuring personal protective equipment and hospital supplies and paying salaries to healthcare workers. National professional groups - including medical associations, veterinarians, scientists, the media and non-governmental organisations - must make their expertise available for the service and welfare of their communities. International agencies and governments must also take decisive action, deploying the appropriate resources to contain the epidemic.

Competing interests: I have read and understood BMJ policy on declaration of interests and have no interests to declare.

Provenance and peer review: Commissioned; not externally peer reviewed.

1 Baize S, Pannetier D, Oestereich L, Rieger T, Koivogui L, Magassouba N, et al. Emergence of Zaire Ebola virus disease in Guinea-preliminary report. N Engl J Med 16 April. [Epub ahead of print].
2 World Health Organization. Ebola virus disease. Fact sheet No 103. 2014. www.who.int/ mediacentre/factsheets/fs103/en/.

3 World Health Organization. WHO: Ebola response roadmap update, 8 September 2014 http://apps.who.int/iris/bitstream/10665/132834/1/roadmapupdate8sept14_eng.pdf?ua=18 $\mathrm{ua}=1$.

4 World Health Organization. WHO statement on the meeting of the International Health Regulations Emergency Committee regarding the 2014 Ebola outbreak in west Africa. 2014. www.who.int/mediacentre/news/statements/2014/ebola-20140808/en/.

5 United Nations Development Programme. Sustaining human progress: reducing vulnerabilities and building resilience (2014 human development report). www.undp.org/ content/undp/en/home/librarypage/hdr/2014-human-development-report.html.

6 Bausch DG, Schwarz L. Outbreak of Ebola virus disease in Guinea: where ecology meets economy. PLoS Negl Trop Dis 2014;8:e3056.

7 World Health Organization. World health statistics 2013. www.who.int/gho/publications/ world_health_statistics/2013/en/

8 World Health Organization. Unprecedented number of medical staff infected with Ebola 2014. www.who.int/mediacentre/news/ebola/25-august-2014/en/.

9 Ebola crisis to last "at least six months"-MSF. BBC News 2014 Aug 15. www.bbc.com/ news/world-africa-28807281.

10 Médecins Sans Frontières. Ebola: the failures of the international outbreak response. 2014. www.msf.org/article/ebola-failures-international-outbreak-response.

Cite this as: BMJ 2014;349:95597

๑ BMJ Publishing Group Ltd 2014 